\title{
Efficiency and applicability of comprehensive geriatric assessment in the Emergency Department: a systematic review
}

\author{
Christophe E. Graf, Dina Zekry, Sandra Giannelli, Jean-Pierre Michel and Thierry Chevalley \\ Rehabilitation and Geriatrics Department, Geneva University Hospitals, Thônex, Switzerland
}

\begin{abstract}
Background and aims: Comprehensive geriatric assessment (CGA) may benefit frail or chronically ill patients in the emergency department (ED), but take too much time to be performed routinely in ED. An alternative approach is to use first a screening tool to detect high-risk patients and then perform CGA in these patients only. This systematic review focuses on the use and value of CGA in ED for evaluation of older patients and its influence on adverse outcomes. This approach is compared with an alternative one using existing screening tools, validated in $E D$, to detect high-risk patients needing subsequent CGA. This review ends by suggesting a short assessment of CGA to be used in ED and ways to improve home discharge management from ED. Methods: A systematic English Medline literature search was conducted in December 2009, with no date limit with the following Medical Subject Heading (MeSH) terms: "Frail Elderly", "Health Services for Aged", "Community Health Nursing", "Emergency Service, Hospital", "Geriatric Assessment", "Patient Discharge", "Risk Assessment" and "Triage". Results: We selected 8 studies on CGA efficiency and 14 on screening tools. CGA in ED is efficient for decreasing functional decline, ED readmission and possibly nursing home admission in high-risk patients. As CGA takes too much time to be performed routinely in $E D$, validated screening tools can be applied to detect high-risk patients who will benefit most from CGA. Conclusions: The selected studies demonstrated that screening of high-risk patients is more efficient than age-based screening, and that CGA performed in ED, followed by appropriate interventions, improves outcomes. (Aging Clin Exp Res 2011; 23: 244-254)

(02011, Editrice Kurtis
\end{abstract}

\section{INTRODUCTION}

Emergency department (ED) admissions of older patients are increasing and account for $15 \%$ of all consultations (1). Annually in Italy, the average percentage of ED visits for persons aged 75 and older is 58 visits $/ 100$ persons-year, compared with 38 visits $/ 100$ persons-year for people under 65 years (2). In addition, older patients spend more time in $\mathrm{ED}$, frequently have more severe diseases than younger patients, and often suffer from polymorbidity. However, geriatric syndromes like functional decline or delirium are frequently underrecognized (3). In a French transversal study including 1298 patients over the age of 80 , a quarter $(24.2 \%)$ directly returned home after an ED admission (4). However, this population is at high risk of adverse outcomes like ED readmission, hospitalization, functional decline, nursing home admission and death (5).

Comprehensive geriatric assessment (CGA) is a multidisciplinary tool with cognitive and mood evaluation, examination of comorbidities and polypharmacy, assessment of risk of falls and functional status (basic activities of daily living [BADL] and instrumental activities of daily living [IADL]), as well as nutritional status and social support (6). It has been shown that ambulatory CGA and subsequent specific interventions improve function, diminish hospitalization and institutionalization rate, and may prolong survival (7).

In $\mathrm{ED}, \mathrm{CGA}$ is useful for identifying unknown geriatric syndromes or problems, in order to help ED physicians manage such patients (8). It identifies two new geriatric problems per patient, which had not been noted routinely by the ED physician (3). However, CGA is a time-consuming process, which may be problematic in ED. There-

Key words: Comprehensive geriatric assessment, Emergency department, geriatric outcomes, high-risk patients, screening tools.

Correspondence: Dr. Christophe Graf, Rehabilitation and Geriatrics Department, Geneva University Hospitals, 3, chemin du Pont-Bochet, 1226 Thônex, Switzerland.

E-mail: christophe.graf@hcuge.ch

Received June 1, 2010; accepted in revised form August 31, 2010.

First published ahead of print October 5, 2010 as DOI: 10.3275/7284 
fore, simplified screening tools have been developed in order to detect patients at risk of adverse outcomes (9). These tools allow patients to be classified as low-risk, i.e. ones who do not need any special evaluation, and highrisk, i.e. ones who will benefit by CGA and subsequent interventions (10).

This systematic review focuses on the use and value of CGA in ED for evaluations of older patients and its influence on adverse outcomes. This approach is compared with an alternative one using existing screening tools, validated in $\mathrm{ED}$, to detect high-risk patients needing subsequent CGA. This review ends by suggesting a short assessment of CGA to be used in ED and ways to improve home discharge management from ED.

\section{BACKGROUND}

\section{Adverse geriatric outcomes}

After an ED visit, older people are at risk of hospital readmission, functional decline, institutionalization and death. Mion et al. showed that readmission to ED of elders over 65 years was $15 \%$ and $40 \%$ at 30 days and 4 months respectively (11). A quarter of these ED-readmitted patients had been hospitalized (12). Four months after an ED visit, one third had functional decline, defined as reduced ability to perform tasks of everyday living because of a decrease in physical and/or cognitive functioning (13), and $4 \%$ of those over 65 had been institutionalized at 4 months (11). In a large Canadian cohort of subjects aged over 65 (12), the rate of death at 30 days after an ED visit was $1 \%$, but reached $13 \%$ at 90 days among patients over 75 (14).

\section{Components of CGA}

CGA aims at assessing the most important geriatric concerns such as delirium, cognitive impairment, depression, BADL and IADL dependence, risk of falls, malnutrition and polypharmacy. These components and their epidemiology are listed in Table 1.

Delirium is frequent on admission and is associated with long-term cognitive decline (15). Subjects in whom delirium is not detected by ED physicians or nurses have the highest mortality (30\%) over 6 months (16). Similarly, dementia has a high prevalence in ED (17), and its presence may affect compliance with medication and discharge instructions, increasing the risk of morbidity and mortality after ED discharge. Older subjects with depression consume more medical resources and have higher ED readmission rates $(18,19)$. It has also been shown that untreated depression may lead to functional decline (20).

Functional status is consistently found to be correlated with length of stay (21), and is closely related to adverse outcomes (22). Falls are a major geriatric problem and may result in serious injury. In community-dwelling patients over 70 , the prevalence of falls at 9 months was $33 \%$ (23). Two percent of fallers were reported to suffer from hip fracture and $4 \%$ from forearm fracture. After an ED visit, older patients who fell are more at risk of further falls (24) and functional decline (25). The prevalence of malnutrition may affect $15 \%$ of community-dwelling elders, $62 \%$ of hospitalized patients, and up to $85 \%$ of nursing home residents (26). Malnourished patients over 65 have double the risk of ED admission (27).

Polypharmacy is a major problem among older people. The definition of polypharmacy varies in the literature, ranging from $\geq 2$ concomitant drugs to $\geq 5$ (28). Using this last definition, Jorgensen et al. reported a prevalence of $39 \%$ among people over 65 (29). The elderly have poor knowledge of their medication doses. Indeed, Chung et al. (30) showed that $57 \%$ of patients over 65 were unable to identify all their prescription medications correctly, and the likelihood of missing the name of at least one medication increased with the total number of drugs. Age-related physiological changes also influence pharmacokinetics and pharmacodynamics (31). For all these reasons, older people are more at risk of adverse drug-related events (ADE) (32). The annual incidence of ED ADE in the United States was estimated at $4.9 \%$ of patients over 65 and increased with age (33). ADE accounted for $5.9 \%$ of

Table 1 - Components of comprehensive geriatric assessment and epidemiology.

\begin{tabular}{|c|c|c|c|c|}
\hline & $\begin{array}{l}\text { Prevalence } \\
\text { in ED }\end{array}$ & $\begin{array}{l}\text { Influence } \\
\text { on length } \\
\text { of stay }\end{array}$ & $\begin{array}{c}\text { Identification } \\
\text { by ED } \\
\text { physicians }\end{array}$ & Mortality \\
\hline Delirium & $10 \%(77)$ & No (78) (79) & $24 \%(80)$ & HR 2.1 at 1 year (81), RR 2.3 at 3 years (82) \\
\hline Cognitive impairment & $20 \%(17)$ & Yes (78) & $46 \%(17)$ & RR 1.7 at 3 years $(82)$ \\
\hline Depression & $27 \%(83)$ & No (78) & $33 \%(84)$ & RR 1.6 after 27 years of follow-up (85) \\
\hline Functional dependence & Up to $75 \%(3)$ & Yes (21) & $25 \%(3)$ & RR 2.1 at 3 years (82) \\
\hline Risk of falls & $15 \%(86)$ & Yes (78) & - & RR 3.2 during following year (87) \\
\hline Malnutrition & $20 \%(40)$ & Yes (78) & - & RR 2.8 at 4 years $(88)$ \\
\hline Polypharmacy ( $\geq 5$ drugs) & $40 \%(32)$ & Yes (89) & - & OR 1.9 during hospitalization (89) \\
\hline
\end{tabular}

HR: hazard ratio; OR: odds ratio; RR: relative risk. 


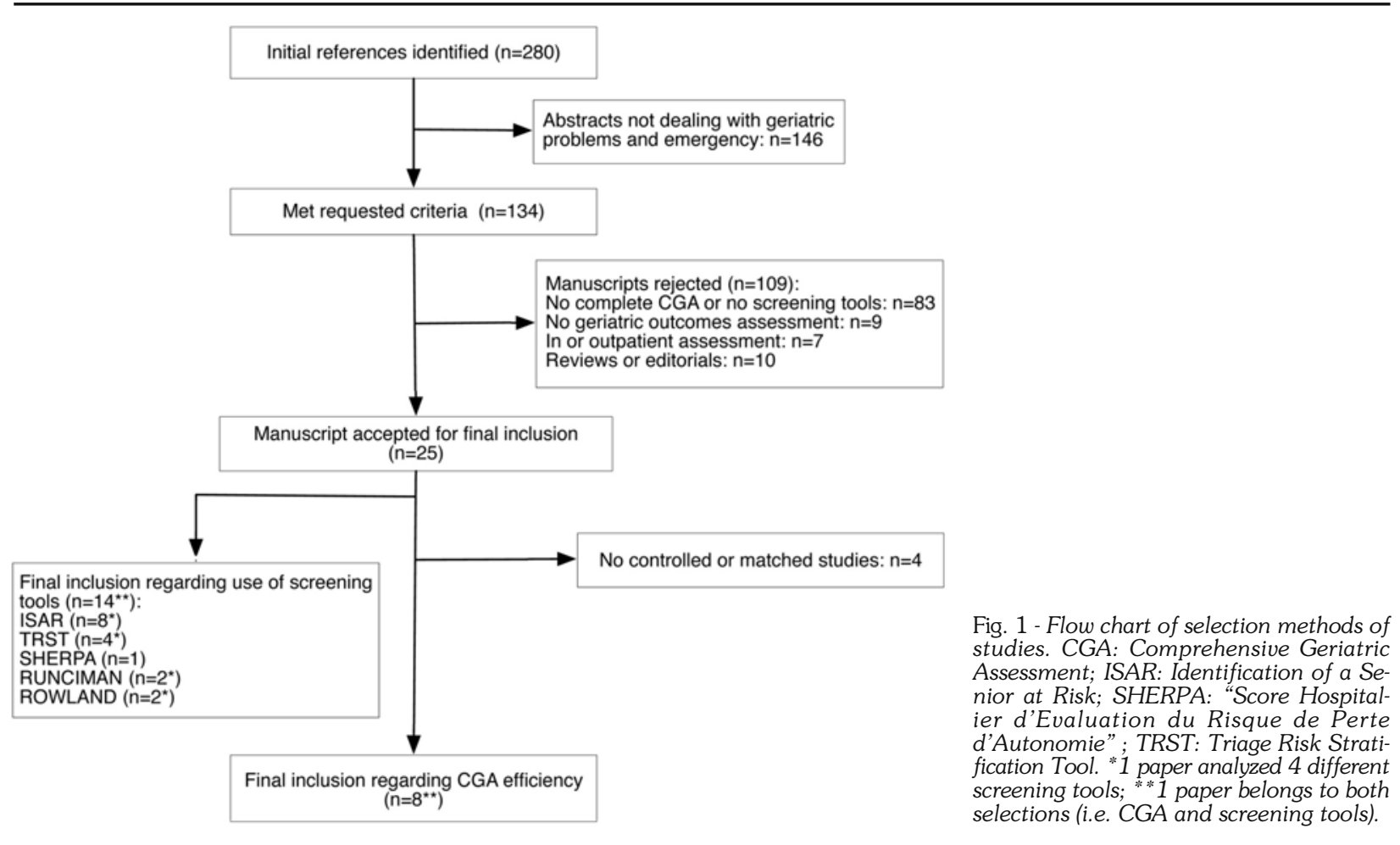

ED visits among older patients admitted for unintentional injuries (33), and may increase the risk of falls by $70 \%$ in subjects over 60 (34), lead to fractures in $24 \%$ of cases, and to delirium in $14 \%$ (35).

By identifying a mean of two new geriatric problems, compared with usual clinical evaluation, CGA may decrease the onset of adverse outcomes (36).

\section{METHODS}

\section{Literature search}

A systematic English MEDLINE literature search of published cohort studies, case-control studies, case-matched studies and cross-sectional studies without any date limit was performed in December 2009. The following Medical Subject Heading $(\mathrm{MeSH})$ terms were used: "Community Health Nursing", "Emergency Service, Hospital", "Emergency Treatment", "Frail Elderly", "Geriatric Assessment", "Health Services for Aged", "Patient Discharge", "Risk Assessment" and "Triage". They were combined in the following equation: "((Emergency Service, Hospital[MeSH Major Topic]) AND (Emergency Treatment[MeSH Major Topic]) AND (Patient Discharge[MeSH Major Topic])) OR ((Activities of Daily Living[MeSH Major Topic]) AND (Patient Discharge[MeSH Major Topic])) OR ((Patient Discharge[MeSH Terms]) AND (Risk Assessment[MeSH Terms]) AND (Triage[MeSH Major Topic])) OR ((Frail El-
derly[MeSH Major Topic]) AND (Health Services for Aged[MeSH Major Topic]) AND (Community Health Nursing[MeSH Major Topic])) OR ((Health Services for Aged[MeSH Major Topic]) AND (Emergency Service, Hospital[MeSH Major Topic])) OR ((Emergency Service, Hospital[MeSH Terms]) AND (Geriatric assessment[MeSH Major Topic]))".

\section{Study selection and analysis}

The abstracts identified in the literature were evaluated by one reviewer (CEG). For abstracts fulfilling the initial inclusion criteria (subject dealing with geriatric problems in ED), full articles were obtained. Articles with complete CGA (for example, not only fall risk assessment), screening tools validated in $\mathrm{ED}$, adverse geriatric outcome assessment, and no inpatient or outpatient assessment were selected for final analysis. Regarding studies on CGA efficiency, only controlled or matched studies were included.

Study selection is shown on a flow chart (Fig. 1). One hundred and thirty-four of the 280 identified abstracts were selected according to the initial inclusion criteria. Further revision excluded 109 studies, as they did not use complete CGA or screening tools $(n=83)$, did not assess geriatric outcomes $(n=9)$, did not concern patients in ED $(n=7)$, or were reviews or editorials $(n=10)$. In the fi- 
nal phase, 4 studies regarding CGA efficiency were excluded because of lack of a control or matched group. Lastly, we included 8 studies on CGA $(10,11,36-41)$ and 14 on screening tools $(9,41-53)$ ( 1 study belongs to both selections).

\section{RESULTS}

\section{Comprehensive geriatric assessment}

Seven randomized and one matched controlled trials dealt with CGA in ED and subsequent geriatric intervention (Table 2). One study was conducted in a tertiary hospital (37) and the others in university teaching hospitals. Except in the study by Mion et al. (11), CGA was performed by nurses. Although the authors used various validated tests for CGA, they all included an assessment of mental and functional status, social support, resource utilization, and polypharmacy statement.

Three studies showed no advantage in performing CGA with regard to outcome (functional decline, ED readmission, institutionalization, death) $(37,38,40)$. The other five studies showed a reduction in functional decline after CGA in ED (10, 11, 36, 39, 41). Mion et al. (11) found a decrease in institutionalization, which was not confirmed by Caplan et al. (36). In contrast with other studies $(11,36,39)$, McCusker et al. (48) described an increase in ED readmission at 30 days, especially for patients without primary physicians. Regarding mortality, no evidence was found that carrying out CGA in ED had any effect.

Table 2 - Randomized/matched controlled trials studying comprehensive geriatric assessment applied to older people, and its influence on adverse outcomes (functional decline, ED readmission, institutionalization and death).

\begin{tabular}{|c|c|c|c|c|c|}
\hline $\begin{array}{l}\text { Studies } \\
\text { (RCT) }\end{array}$ & Population & Intervention & Outcomes & Results & Limitations \\
\hline $\begin{array}{l}\text { Miller DK } \\
1996(40)\end{array}$ & $\begin{array}{l}>65 \text { yrs discharged } \\
\text { or hospitalized } \\
\text { after } E D \text { visit. } \\
\text { INT }=385 / C O=385\end{array}$ & $\begin{array}{l}\text { CGA in ED by nurses. } \\
\text { Referral to community } \\
\text { services. }\end{array}$ & $\begin{array}{l}\text { Mortality. } \\
\text { Institutionalization. } \\
\text { Functional decline. } \\
\text { ED readmission at } \\
3 \text { months. }\end{array}$ & $\begin{array}{l}\text { No significant } \\
\text { difference. }\end{array}$ & $\begin{array}{l}\text { Not randomized. } \\
\text { Recommendations } \\
\text { at ED discharge poorly } \\
\text { followed (39\%). } \\
\text { No high-risk patient } \\
\text { screening }\end{array}$ \\
\hline $\begin{array}{l}\text { Gagnon AJ } \\
1999(38)\end{array}$ & $\begin{array}{l}>70 \text { yrs. Screening } \\
\text { by a hospital } \\
\text { admission risk tool. } \\
\text { Discharged home. } \\
\text { INT }=212 / \mathrm{CO}=215\end{array}$ & $\begin{array}{l}\text { Nurse case } \\
\text { management. } \\
\text { Phone call follow-up } \\
\text { and home visit every } \\
\text { six weeks. }\end{array}$ & $\begin{array}{l}\text { ED readmission. } \\
\text { Functional decline. } \\
\text { Mortality at } \\
10 \text { months. }\end{array}$ & $\begin{array}{l}\text { Increase of ED } \\
\text { readmission. } \\
\text { No difference in } \\
\text { functional decline } \\
\text { or mortality. }\end{array}$ & $\begin{array}{l}\text { No validated tools } \\
\text { to identify high-risk } \\
\text { patients. } \\
\text { Up to } 16 \text { weeks between } \\
\text { ED visit and intervention. }\end{array}$ \\
\hline $\begin{array}{l}\text { Basic D } \\
2005 \text { (37) }\end{array}$ & $\begin{array}{l}>70 \text { yrs discharged } \\
\text { or hospitalized after } \\
\text { ED visit. } \\
\text { INT }=114 / C O=110\end{array}$ & $\begin{array}{l}\text { CGA in ED by } \\
\text { nurses and referral to } \\
\text { community services. }\end{array}$ & $\begin{array}{l}\text { ED readmission } \\
\text { at } 10 \text { days. }\end{array}$ & $\begin{array}{l}\text { No significant } \\
\text { difference. }\end{array}$ & $\begin{array}{l}\text { High-risk patient } \\
\text { selection according } \\
\text { to nurses' subjective } \\
\text { evaluation. }\end{array}$ \\
\hline $\begin{array}{l}\text { Runciman P } \\
1996 \text { (41) }\end{array}$ & $\begin{array}{l}>75 \text { yrs discharged } \\
\text { home after trauma. } \\
\text { INT }=222 / C O=192\end{array}$ & $\begin{array}{l}\text { Home visit for } \\
\text { assessment and referral } \\
\text { to community services. }\end{array}$ & $\begin{array}{l}\text { BADL and IADL } \\
\text { assessment. } \\
\text { ED readmissions } \\
\text { at four weeks. }\end{array}$ & $\begin{array}{l}14 \% \text { reduction of IADL } \\
\text { dependent patients. } \\
\text { No difference in BADL } \\
\text { or ED readmissions. }\end{array}$ & $\begin{array}{l}\text { No high-risk patient } \\
\text { screening. Post-trauma } \\
\text { population. } \\
\text { Incomplete CGA. }\end{array}$ \\
\hline $\begin{array}{l}\text { Mion LC } \\
2003(11)\end{array}$ & $\begin{array}{l}>65 \text { yrs. Screening } \\
\text { by a high-risk patient } \\
\text { tool (TRST score). } \\
\text { Discharged home. } \\
\text { INT }=326 / C O=324\end{array}$ & $\begin{array}{l}\text { CGA in ED by research } \\
\text { assistants and referral } \\
\text { to community services. }\end{array}$ & $\begin{array}{l}\text { ED readmission. } \\
\text { Institutionalization. } \\
\text { Death at } 30 \text { and } \\
120 \text { days. }\end{array}$ & $\begin{array}{l}\text { Decreased } \\
\text { institutionalization } \\
\text { at } 30 \text { and } 120 \text { days for } \\
\text { high-risk patients. } \\
\text { No effect on ED } \\
\text { readmission and death. }\end{array}$ & $\begin{array}{l}\text { Small number of } \\
\text { patients admitted } \\
\text { to nursing homes. }\end{array}$ \\
\hline $\begin{array}{l}\text { Caplan GA } \\
2004(36)\end{array}$ & $\begin{array}{l}>75 \text { yrs } \\
\text { discharged home. } \\
\text { INT }=370 / C O=369\end{array}$ & $\begin{array}{l}\text { CGA at home by nurses. } \\
4 \text { weeks follow-up by } \\
\text { weekly inter-disciplinary } \\
\text { team. }\end{array}$ & $\begin{array}{l}\text { Functional decline. } \\
\text { Institutionalization. } \\
\text { ED readmission. } \\
\text { Mortality at } 1,6 \text {, } \\
12 \text { and } 18 \text { months. }\end{array}$ & $\begin{array}{l}\text { 10\% reduction of } \\
\text { ED-readmission at } \\
18 \text { months (NNT 10). } \\
\text { Decrease in functional } \\
\text { decline at } 6 \text { months. } \\
\text { No effect on other items. }\end{array}$ & $\begin{array}{l}\text { No significant } \\
\text { limitations. }\end{array}$ \\
\hline $\begin{array}{l}\text { McCusker J } \\
2001(10)\end{array}$ & $\begin{array}{l}>65 \text { yrs. Screening } \\
\text { by a high-risk patient } \\
\text { tool (ISAR score). } \\
\text { Discharged home. } \\
\text { INT }=178 / C O=210\end{array}$ & $\begin{array}{l}\text { CGA in ED by } \\
\text { nurses and referral to } \\
\text { community services } \\
\text { for high-risk patients } \\
\text { (ISAR } \geq 2 \text { ). }\end{array}$ & $\begin{array}{l}\text { Functional decline } \\
\text { or mortality at } \\
120 \text { days. }\end{array}$ & $\begin{array}{l}45 \% \text { reduction of } \\
\text { functional decline or } \\
\text { mortality at } 120 \text { days. } \\
\text { Increase in ED } \\
\text { readmission at } 30 \text { days. }\end{array}$ & $\begin{array}{l}\text { No significant } \\
\text { limitations. }\end{array}$ \\
\hline $\begin{array}{l}\text { Guttmann A } \\
2004 \text { (39) }\end{array}$ & $\begin{array}{l}>75 \text { yrs } \\
\text { discharged home. } \\
\text { INT }=2679 / \mathrm{CO}=2634\end{array}$ & $\begin{array}{l}\text { CGA in ED by nurses. } \\
14 \text { days follow-up }\end{array}$ & $\begin{array}{l}\text { ED readmission at } \\
1,8 \text { and } 14 \text { days. }\end{array}$ & $\begin{array}{l}\text { Decrease in ED } \\
\text { readmission at } 8 \\
\text { and } 14 \text { days. }\end{array}$ & $\begin{array}{l}\text { No significant } \\
\text { limitations. }\end{array}$ \\
\hline
\end{tabular}


Table 3 - Emergency department validation studies of screening tools used to select high-risk elderly people discharged from hospital.

\begin{tabular}{|c|c|c|c|c|}
\hline $\begin{array}{l}\text { Screening } \\
\text { tools }\end{array}$ & Settings & Items & $\begin{array}{l}\text { Cut-offs and } \\
\text { performances }\end{array}$ & Outcomes \\
\hline SHERPA (42) & $\begin{array}{l}\text { Two general teaching } \\
\text { hospitals (Belgium). } \\
\text { Nurses' evaluation. } \\
\mathrm{N}=550 />70 \text { yrs }\end{array}$ & $\begin{array}{l}\text { History of falls ( } 1 \text { year). } \\
\text { Cognitive evaluation (MMSE). } \\
\text { Self-perceived health. } \\
\text { Age (<75; 75-84; }>84 \text { yrs). } \\
\text { IADL dependence (Lawton, } 7 \text { items). }\end{array}$ & $\begin{array}{l}\geq 3.5 / 11.5 \\
\text { Sensitivity } 85 \% \\
\text { Specificity } 45 \%\end{array}$ & $\begin{array}{l}\text { Functional decline. } \\
\text { Hospitalization. } \\
\text { Death at } 3 \text { months. }\end{array}$ \\
\hline Runciman P (41) & $\begin{array}{l}\text { ED of university } \\
\text { hospital (UK). } \\
\text { Nurses' evaluation. } \\
\mathrm{N}=48 />75 \text { yrs }\end{array}$ & $\begin{array}{l}\text { Recent trauma (few days). } \\
\text { BADL dependence ( } 1 \text { item). } \\
\text { IADL dependence ( } 2 \text { items). } \\
\text { Use of diuretics /Incontinence. } \\
\text { Walking problems. } \\
\text { Short-term memory problems. }\end{array}$ & $\begin{array}{l}\geq 2 / 8 \\
\text { Sensitivity } 86 \% \\
\text { Specificity } 38 \%\end{array}$ & $\begin{array}{l}\text { ED readmission } \\
\text { at } 28 \text { days. }\end{array}$ \\
\hline Rowland K (51) & $\begin{array}{l}\text { ED of university } \\
\text { hospital (UK). } \\
\text { Nurses' evaluation. } \\
\mathrm{N}=555 />75 \text { yrs }\end{array}$ & $\begin{array}{l}\text { BADL dependence ( } 2 \text { items). } \\
\text { IADL dependence ( } 3 \text { items). } \\
\text { Walking problems. } \\
\text { Day center/hospital use. }\end{array}$ & $\begin{array}{l}\geq 4 / 7 \\
\text { Sensitivity } 85 \% \\
\text { Specificity } 28 \%\end{array}$ & $\begin{array}{l}\text { ED readmission } \\
\text { at } 14 \text { days. }\end{array}$ \\
\hline TRST (50) & $\begin{array}{l}\text { Two urban } \\
\text { teaching ED (USA). } \\
\text { Self-reported or } \\
\text { nurses evaluation. } \\
\mathrm{N}=647 />65 \text { yrs }\end{array}$ & $\begin{array}{l}\text { Cognitive impairment. } \\
\text { Walking/transferring problems. } \\
\text { Polypharmacy ( }>5) \\
\text { Hospitalization ( } 3 \text { months) } \\
\text { or ED use ( } 1 \text { month). } \\
\text { Lives alone, or no caregiver. } \\
\text { Nurses registered concern. }\end{array}$ & $\begin{array}{l}\geq 2 / 6 \\
\text { Sensitivity } 64 \% \text { at } 30 \text { days, } \\
55 \% \text { at } 120 \text { days. } \\
\text { Specificity } 63 \% \text { at } 30 \text { days, } \\
66 \% \text { at } 120 \text { days. }\end{array}$ & $\begin{array}{l}\text { ED readmission and } \\
\text { Institutionalization } \\
\text { at } 30 \text { and } 120 \text { days. }\end{array}$ \\
\hline ISAR (47) & $\begin{array}{l}\text { Four ED university-affiliated } \\
\text { hospitals (CAN). } \\
\text { Self-reported or nurses' } \\
\text { evaluation. } \\
\mathrm{N}=676 />65 \text { yrs }\end{array}$ & $\begin{array}{l}\text { BADL dependence } \\
\text { (1 general question). } \\
\text { IADL dependence } \\
\text { (1 general question). } \\
\text { Visual impairment. } \\
\text { Cognitive impairment. } \\
\text { Previous hospitalization } \\
\text { (6 months). } \\
\text { Polypharmacy (>3). }\end{array}$ & $\begin{array}{l}\geq 2 / 6 \\
\text { Sensitivity } 72 \% \\
\text { Specificity } 58 \%\end{array}$ & $\begin{array}{l}\text { Death. } \\
\text { Institutionalization. } \\
\text { Functional decline } \\
\text { at } 6 \text { months. }\end{array}$ \\
\hline
\end{tabular}

BADL: Basic Activities of Daily Living; CGA: Comprehensive Geriatric Assessment; ED: Emergency Department; MMSE: Mini-Mental State Evaluation; ISAR: Identification of a Senior at Risk; SHERPA: "Score Hospitalier d'Evaluation du Risque de Perte d'Autonomie"; TRST: Triage Risk Stratification Tool.

\section{Screening tools to detect high-risk patients}

Five screening tools to identify high-risk populations have been developed for patients discharged from ED or hospital, and predict adverse outcomes (9). The ED validation studies of these screening tools, "Score Hospitalier d'Evaluation du Risque de Perte d'Autonomie" (SHERPA), Runciman, Rowland, Triage Risk Stratification Tool (TRST) and Identification of a Senior at Risk (ISAR) (41, 42, 47, $50,51)$ are listed in Table 3.

The performance of these screening tools varies. SHERPA has good performance to predict functional decline, hospitalization and death at 3 months, but fails to predict ED readmission (42). The four other screening tools (Runciman, Rowland, TRST, ISAR) show similar initial performance. Recently, Moons et al. conducted a study of 83 patients over 65 in a Belgian teaching hospital and compared these four screening tools (9). They found that the sensitivity of Runciman test decreased within three months from $80 \%$ to $59 \%$. In contrast with the original article (specificity of $28 \%$ ), Moons et al. described the Rowland test as having good specificity (75\% at 1 month $-76 \%$ at 3 months) and negative predictive value ( $92 \%$ at 1 month - $78 \%$ at 3 months) for ED readmission. The TRST is not sensitive for this outcome (9). This was confirmed by a recent prospective study on 788 patients over 65 in three hospitals in Toronto ( 1 suburban community hospital, 1 urban community hospital, and one urban teaching hospital), which demonstrated that a routinely performed TRST was not sensitive in predicting ED readmission $(70 \%$ at 1 month $62 \%$ at 3 months) (45). A second data analysis of the study by Mion et al. (50) also showed that the TRST failed to predict functional decline (44). According to Moons et al., the negative predictive value of the ISAR for ED readmission is $100 \%, 89 \%$ and $82 \%$ at 14 days, 1 month and 3 months, respectively (9). In an Italian prospective study of 200 patients over 65 in two urban hospitals (1 teaching and 1 tertiary hospital), an ISAR $\geq 2 / 6$ was strongly predictive of adverse outcomes at 6 months (adjusted OR 3.46, 95\% CI 1.68-7.15) (52). As mentioned before, this tool is validated in a two-step approach (10).

The last four selected studies did not deal with adverse outcomes. In a second data analysis of the two studies by 
McCuskey et al. (10,47), the ISAR predicted high use of community health centers (43), was cost-effective (49) and improved communication with primary care services (48). The last study emphasized that some questions of the ISAR may not be appropriate for patients over 75 (53).

\section{DISCUSSION}

Value of CGA in the emergency department

Negative studies $(37,38,40)$ had several limitations. The study by Miller et al. (40) was not randomized, but matched a control group with an assembled intervention cohort. In addition, the recommendations for patients at ED discharge were poorly followed (39\% in intervention group). The authors suggested that it was due to poorly coordinated health providers in the United States. There was no screening of high-risk patients. Gagnon et al. (38) tried to identify high-risk patients, but did not use a validated screening tool, and concluded that their selection criteria might not have been sensitive enough; nor did they deliver the intervention during or immediately after the $\mathrm{ED}$ visit, which could be delayed for up to 16 weeks. In the study by Basic et al. (37), selection of high-risk patients was dependent on nurses' evaluations, but was not based on a validated tool. The intervention and control groups were not similar as regards gender and health status at inclusion (sicker intervention group), and the short follow-up of 10 days may explain the negative results. Thus, negative results may originate, at least partly, from study limitations.

The other five studies $(10,11,36,39,41)$ found some positive effects, but had various designs. Runciman et al. (41) showed a reduction in functional decline, but the lack of high-risk patient identification, the specificity of the studied population (post-trauma) and the incomplete CGA used (only BADL/IADL/mental status examination) explained the negative effect concerning $\mathrm{ED}$ readmission. The others were methodologically stronger and confirmed reduced functional decline after $\mathrm{CGA}$ in $\mathrm{ED}(10,11,36,39)$.

Regarding the other adverse outcomes, the results are more controversial. Mion et al. (11) found a decrease in institutionalization, but the small number of patients admitted to nursing homes during follow-up weakens the significance of these results. Despite the lower age of participants, studies with screening of high-risk patients had better results, especially as regards functional decline $(10,11)$.

Collectively, these results demonstrate that screening of high-risk patients is more efficient that age-based screening, and that CGA performed in ED improves adverse outcomes. As CGA is time-consuming and cannot be applied routinely in $\mathrm{ED}$, it should be reserved for high-risk patients, i.e. ones for whom it is most efficient (39).

Screening tools to identify high-risk patients needing CGA

An ideal screening tool must be easy to use, rapid and simple, have good sensitivity and negative predictive val- ue, and good reproducibility. The SHERPA takes too long to perform in ED, as it includes a Mini-Mental State Evaluation (MMSE) (42). The Runciman test is longer and more complex than the others. The Rowland test does not contain a mental evaluation. The only two screening tools validated and studied with a two-step approach (screening tool in order to identify high-risk patients, followed by CGA), are TRST and ISAR $(47,50)$. As regards recent TRST results, this tool is not accurate enough for routine use in $\operatorname{ED}(44,45)$. Consequently, the best screening tool seems to be the ISAR. It allows an exhaustive overview of geriatric risk factors, and identifies high-risk patients for adverse outcomes with good testretest reliability (46). It can be performed in 2 minutes or integrated in nurses' general evaluation.

\section{PRACTICAL SUGGESTIONS FOR APPLICATION OF CGA IN ED}

\section{Short assessment of CGA in ED}

Even with a two-step approach, the application of CGA is time-consuming. Some shorter assessment tools for CGA have been validated in ED (Table 4).

The Confusion Assessment Method (CAM) contains 4 features and is the most widely used instrument to diagnose delirium, with excellent performance (54). The MMSE is used worldwide and validated for cognitive impairment screening in ED (55). However, it takes up to 14 minutes to finish (56), and is therefore difficult to implement as part of CGA. The Mini-Cog is a rapid screening test which can be integrated into routine history and examination without increasing the time needed to evaluate the patient (56). It encompasses a three-item recall and a clock drawing test. It requires intact vision and the ability to write. The Quick Confusion Scale (QCS) can be done faster than the MMSE (it takes about 2 minutes) and does not require writing or reading ability (57). The QCS consists of six questions, including temporal orientation, a working memory task, flexibility testing, and a short-term memory task. According to the literature, it is actually the test with the best performance/time ratio in ED.

The most commonly used tests to detect depression in the elderly are the Geriatric Depression Scale, with 30 (GDS-30) and 15 items (GDS-15), which are similar in terms of sensitivity (89\%) and specificity (62\%) (58). However, they take too long to perform routinely in ED. Two shorter questionnaires are validated in ED. Hustey et al. (59) studied a 2-question score in patients over 70 at ED admission. Similarly, the Emergency Depression Screening Instrument (ED-DSI), a 3-question score, was tested by Fabacher et al. (60). The two types of score had similar results and limitations. The study groups were not randomized and relatively small $(n=267$ and 103, respectively). In addition, GDS was used as the gold standard for diagnosis, instead of a formal psychiatric interview focusing on DSM-IV criteria. Hustey's ques- 
Table 4 - Proposed validated tools for comprehensive geriatric assessment in emergency department.

\begin{tabular}{|c|c|c|c|c|}
\hline Tools & Topics & Cut-offs & Performance & Time \\
\hline CAM (54) & Delirium & $\begin{array}{l}\geq 3 / 4 \text { (items } 1+2 \\
\text { and item } 3 \text { or } 4 \text { ) }\end{array}$ & PPV $100 \%$ and NPV $97 \%$ & $<5 \min (90)$ \\
\hline Mini-Cog (91) & Cognition & $\leq 2 / 5$ & $\begin{array}{l}\text { Sensitivity } 73 \% \text { and NPV } 93 \% \text { compared } \\
\text { with MMSE } \leq 23 / 30 \text { (56) }\end{array}$ & \\
\hline QCS (57) & Cognition & $\leq 11 / 15$ & Correlation with MMSE $\leq 23 / 30(\mathrm{r}=0.783)$ & $2 \min$ \\
\hline $\begin{array}{l}\text { Hustey's } \\
\text { questionnaire (59) }\end{array}$ & Depression & $\geq 1 / 2$ & $\begin{array}{l}\text { Sensitivity } 84 \% \text {, Specificity } 61 \% \text { and } \\
\text { NPV } 95 \% \text { compared with GDS-15 } \geq 5\end{array}$ & $2 \min$ \\
\hline ED-DSI (60) & Depression & $\geq 1 / 3$ & $\begin{array}{l}\text { Sensitivity } 89 \% \text {, Specificity } 73 \% \text { and } \\
\text { NPV } 94 \% \text { compared with GDS-30 } \geq 10\end{array}$ & \\
\hline OARS ADL (64) & Functional status & - & - & $5 \min$ \\
\hline One leg balance (92) & Falls & $\leq 5 \mathrm{sec}$ & RR 3 of injurious falls during next 3 yrs & $5 \min$ \\
\hline Carpenter's score (93) & Falls & $=4 / 4$ & RR 10.3 of falls during next 6 months & $2 \min$ \\
\hline DETERMINE (68) & Malnutrition & $\geq 3$ & $\begin{array}{l}\text { Sensitivity of } 66 \% \text { and NPV } 88 \% \text { compared } \\
\text { with BMI } \leq 18.5 \mathrm{~kg} / \mathrm{m}^{2}\end{array}$ & $5 \mathrm{~min}$ \\
\hline STOPP (74) & Polypharmacy & - & - & $3 \mathrm{~min}$ \\
\hline
\end{tabular}

ADL: Activities of Daily Living; CAM: Confusion Assessment Method; ED_DSI: Emergency Depression Screening Instrument; DETERMINE: DETERMINE Your Nutritional Health Checklist; MMSE: Mini-Mental State Evaluation; OARS: Older American Resources and Services; NPV: Negative Predictive Value; PPV: Positive Predictive Value; QCS: Quick Confusion Scale; RR: Relative Risk; STOPP: Screening Tool of Older People's Potentially Inappropriate Prescriptions.

tionnaire is easier to use, in view of the similar performance, the fact that it is 1 question shorter, and has been validated in more patients than the ED-DSI.

Functional status is assessed by BADL and IADL. The widely used anamnestic scores to assess BADL are the Barthel index (10 items) (61) and the Katz index (6 items) (62). The Barthel index takes too long and is too complex to be routinely used in ED. The Katz index includes six items: bathing, dressing, toilet use, transfer, feeding and continence. For IADL, the most widely used tool is the Lawton scale, which explores 9 items: using the telephone, travel, shopping, meal preparation, housework, taking medicine and management of finances, laundry and mode of transportation (63). The Older American Resources and Services (OARS ADL) questionnaire has the advantage of combining the two indexes and of being validated in ED. It includes the Katz index items ("walking" item added) and 7 items from the Lawton scale (exclusion of the items "laundry" and "mode of transportation") (64). The total score ranges from 0 to 28 . Although the cut-off is not clearly determined (65), each point under the maximum score indicates a functional disability which must be taken into account for further intervention or recommendations. This scale can be performed in 5 minutes.

The timed Get up and Go test is used to assess risk of falls and balance improvement after physiotherapy (66). However, it requires space, and the fact that the patient must be able to walk can make this test difficult or impossible to perform in ED. The "one leg balance" test is defined as the ability to stay on one leg unsupported for 5 seconds. This is a very short and simple test, and the patient only has to be able to stand up. Carpenter et al. reported four anamnestic risk factors predicting falls during the forthcoming 6 months: non healing foot sores, reporting a fall in the past, unable to cut own toenails, and self-reported depression. Thus, the risk of falls could be appreciated in ED by combining a functional test like "one leg balance", and Carpenter's score. However, no studies have actually been done combining these two tests.

For malnutrition screening, the Mini Nutritional Assessment (MNA) (67) can be done in 10-15 minutes, and includes measurement of weight and height for Body Mass Index calculation (BMI). These limitations make its use difficult in ED. The DETERMINE Your Nutritional Health Checklist (DETERMINE) is a self-administered list of ten questions covering different risk factors for malnutrition (68). Four questions cover dietary concerns, four general health assessment, and two social and economic issues. Each question is scored according to its weight defined by the authors. Patients with a total score $\geq 3 / 21$ are at moderate risk of malnutrition, and those with a score $\geq 6 / 21$ are at high risk. Visvanathan et al. found better sensitivity of $66 \%$ and negative predictive value of $88 \%$, when a total score $\geq 3$ was compared with a BMI $\leq 18.5 \mathrm{~kg} / \mathrm{m}^{2}$ (69). Similarly, another study showed sensitivity of $59 \%$ when a cut-off $\geq 6$ was compared with a BMI $\leq 20 \mathrm{~kg} / \mathrm{m}^{2}$ (70). Nevertheless, BMI underestimates malnutrition in ED (71). The DETERMINE list was not constructed to be a diagnostic tool, and should therefore be used only for pre-screening, followed by further nutritional investigations if necessary (72).

It is critical to take advantage of the ED visit to review medication list and make suggestions for improvements, in order to reduce $\mathrm{ADE}$. Prescription of inappropriate drugs 


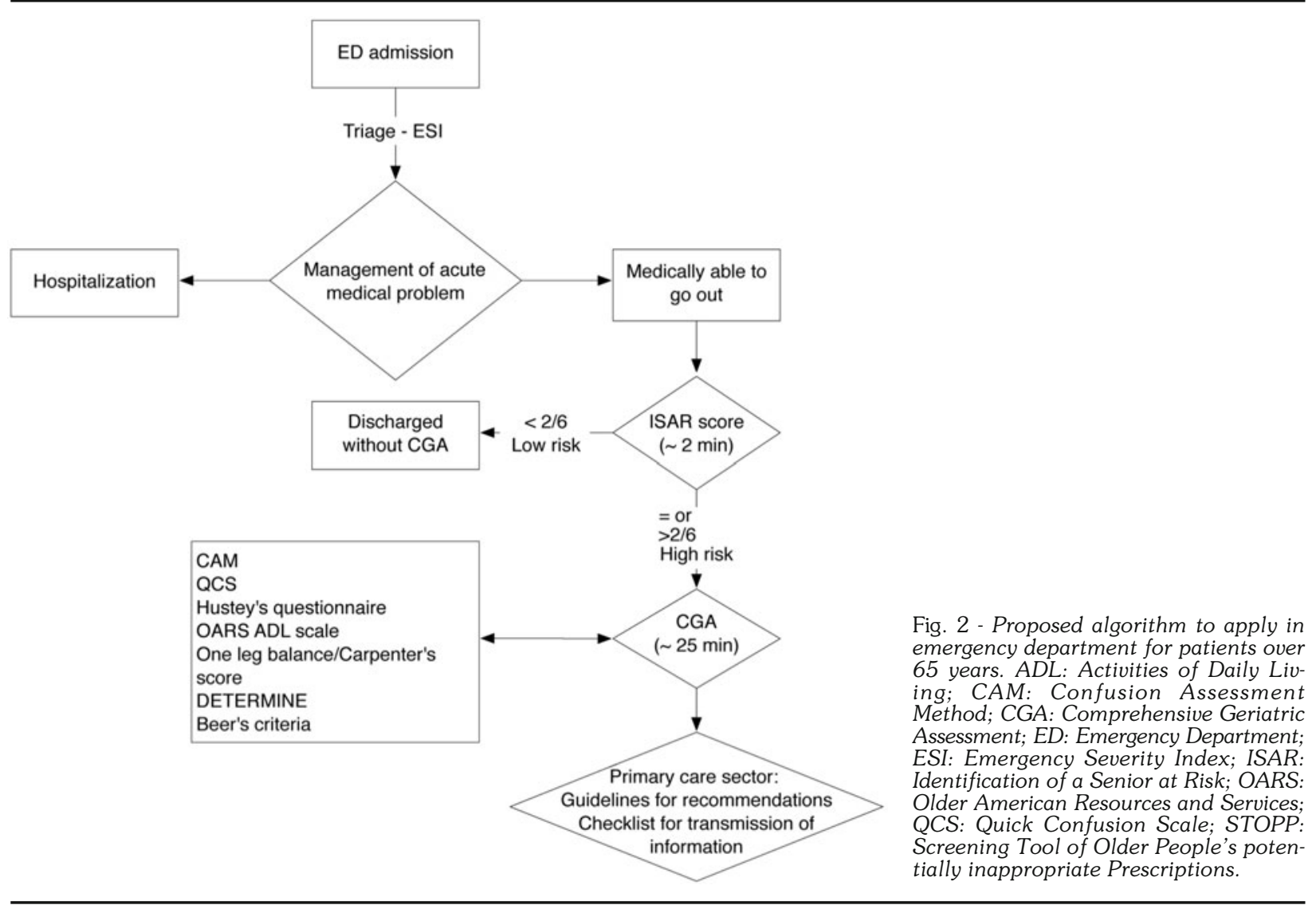

(PID) is associated with a significant increase in ADE (73). A Screening Tool of Older People's potentially inappropriate Prescriptions (STOPP) was recently described (74). STOPP is based on physiological systems, and includes 65 criteria for avoidance of certain drugs interactions in older people. Gallagher et al. showed that STOPP could identify twice more PID than Beer's criteria (75). However, there is no definite evidence that its use can decrease the incidence of $\mathrm{ADE}$.

\section{Organization of home discharge}

As CGA will highlight some geriatric problems and new disabilities, it is crucial to transmit recommendations to primary care physicians and nurses. At present, there are no standardized guidelines to establish such recommendations, and their development would lead to great improvements in home discharge organisation for older patients (41), which have to be personalized and depend on the type of disability. In the literature, there are several methods of organizing the care of older patients after discharge. ED physicians can simply make suggestions to healthcare providers, or activate some specific geriatric ambulatory programs, like falls prevention or cognitive training programs. It is not clear which design gives the best results. For example, McCusker et al. (10) referred to primary care and home services by routine notification to general medical practitioners (GPs) without special follow-up, and obtained a reduction in functional decline. Moreover, such approaches are closely dependent on healthcare systems, which differ between countries.

Communication between the primary care sector and ED must be improved. In a recent study of 79,000 patients over 65 and discharged after an ED visit, McCusker et al. (12) showed that the ED team received medical information from family doctors in only $5 \%$ of cases at ED admission. In the same way, ED team sent the medical information of only $40 \%$ of patients to family doctors. Poor communications between $\mathrm{ED}$ and home care services may worsen the medical follow-up (76). The above authors suggested using a check-list about how, which and when ED physicians and nurses should inform primary care providers, to improve communications. GPs and public health nurses must be informed by telephone or fax to ensure rapidity of transmission. In this way, liaison nurses also have an important role to play to ensure the continuity of care.

According to the above, we propose an algorithm (Fig. 2) to be applied in ED for patients over 65. After man- 
agement of the acute medical problem and if the patient is believed suitable for discharge, a two-step approach is used: determination of high-risk patients by ISAR score (2 min), followed by CGA (25 min). Results lead to personalized recommendations based on guidelines, and the use of a check-list to improve communications between $\mathrm{ED}$ and the primary care sector.

\section{CONCLUSION}

CGA in ED is efficient in decreasing functional decline $(10,11,36,39)$, ED readmissions $(11,36,39)$ and possibly nursing home admissions in high-risk patients (11). However, it takes too long for routine performance in ED. Some ED-validated screening tools, shorter and more routinely applicable than the CGA (like the ISAR), can be applied in order to detect high-risk patients (47). In high-risk patients (defined as those with an ISAR $\geq 2 / 6$ ), CGA should be performed and subsequent recommendations transmitted to primary care professionals. Further research should pursue validation of the twostep approach, to lead to the development of guidelines for discharge management, and to assess the influence of these guidelines on outcomes.

\section{ACKNOWLEDGEMENT}

We would like to thank Dr. L. Genton for technical assistance. Authors disclosure statement: No competing financial interests exist.

\section{REFERENCES}

1. Moritz F, Benez F, Verspyck $V$ et al. [How to manage very elderly patients in the emergency room? Evaluation of 150 very elderly patients at the Rouen University Hospital Center]. Presse Med 2001; 30: 51-4.

2. Salvi F, Morichi V, Grilli A et al. The elderly in the emergency department: a critical review of problems and solutions. Intern Emerg Med 2007; 2: 292-301.

3. Rodriguez-Molinero A, Lopez-Dieguez M, Tabuenca AI et al. Functional assessment of older patients in the emergency department: Comparison between standard instruments, medical records and physicians' perceptions. BMC Geriatr 2006; 6: 13.

4. Lazarovici C, Somme D, Chatellier G et al. [Initial pattern of elderly patients and effect on their orientation after their visit in the emergency departments. Results from a national study]. Rev Med Interne 2008; 29: 618-25.

5. Brennan TA, Leape LL, Laird NM et al. Incidence of adverse events and negligence in hospitalized patients: results of the Harvard Medical Practice Study I. 1991. Qual Saf Health Care 2004; 13: 145-51 (discussion 51-2).

6. Rubenstein LZ, Stuck AE, Siu AL et al. Impacts of geriatric evaluation and management programs on defined outcomes: overview of the evidence. J Am Geriatr Soc 1991; 39: 8S-16S (discussion 17S-18S).

7. Stuck AE, Siu AL, Wieland GD et al. Comprehensive geriatric assessment: a meta-analysis of controlled trials. Lancet 1993; 342: 1032-6.

8. Aminzadeh F, Dalziel WB. Older adults in the emergency department: a systematic review of patterns of use, adverse outcomes, and effectiveness of interventions. Ann Emerg Med 2002; 39: 238-47.
9. Moons P, De Ridder K, Geyskens K et al. Screening for risk of readmission of patients aged 65 years and above after discharge from the emergency department: predictive value of four instruments. Eur J Emerg Med 2007; 14: 315-23.

10. McCusker J, Verdon J, Tousignant P et al. Rapid emergency department intervention for older people reduces risk of functional decline: results of a multicenter randomized trial. J Am Geriatr Soc 2001; 49: 1272-81.

11. Mion LC, Palmer RM, Meldon SW et al. Case finding and referral model for emergency department elders: a randomized clinical trial. Ann Emerg Med 2003; 41: 57-68.

12. McCusker J, Roberge D, Vadeboncoeur A et al. Safety of discharge of seniors from the emergency department to the community. Healthc Q 2009; 12 (Spec No Patient): 24-32.

13. Inouye SK, Bogardus ST Jr, Baker DI et al. The Hospital Elder Life Program: a model of care to prevent cognitive and functional decline in older hospitalized patients. Hospital Elder Life Program. J Am Geriatr Soc 2000; 48: 1697-706.

14. Richardson DB. Elderly patients in the emergency department: a prospective study of characteristics and outcome. Med J Aust 1992; 157: 234-9.

15. Jackson JC, Gordon SM, Hart RP et al. The association between delirium and cognitive decline: a review of the empirical literature. Neuropsychol Rev 2004; 14: 87-98.

16. Kakuma R, du Fort GG, Arsenault $L$ et al. Delirium in older emergency department patients discharged home: effect on survival. J Am Geriatr Soc 2003; 51: 443-50.

17. Hustey FM, Meldon SW, Smith MD et al. The effect of mental status screening on the care of elderly emergency department patients. Ann Emerg Med 2003; 41: 678-84.

18. Lee BW, Conwell Y, Shah MN et al. Major depression and emergency medical services utilization in community-dwelling elderly persons with disabilities. Int J Geriatr Psychiatry 2008; 23: 1276-82.

19. Unutzer J, Patrick DL, Simon $G$ et al. Depressive symptoms and the cost of health services in HMO patients aged 65 years and older. A 4-year prospective study. JAMA 1997; 277: 1618-23.

20. Penninx BW, Guralnik JM, Ferrucci L et al. Depressive symptoms and physical decline in community-dwelling older persons. JAMA 1998; 279: 1720-6.

21. Campbell SE, Seymour DG, Primrose WR. A systematic literature review of factors affecting outcome in older medical patients admitted to hospital. Age Ageing 2004; 33: 110-5.

22. McCusker J, Healey E, Bellavance F et al. Predictors of repeat emergency department visits by elders. Acad Emerg Med 1997; 4: 581-8.

23. Stalenhoef PA, Diederiks JP, Knottnerus JA et al. A risk model for the prediction of recurrent falls in community-dwelling elderly: a prospective cohort study. J Clin Epidemiol 2002; 55 : 1088-94.

24. Ganz DA, Bao Y, Shekelle PG et al. Will my patient fall? JAMA 2007; 297: 77-86.

25. Russell MA, Hill KD, Blackberry I et al. Falls risk and functional decline in older fallers discharged directly from emergency departments. J Gerontol A Biol Sci Med Sci 2006; 61: 1090-5.

26. MacIntosh C, Morley JE, Chapman IM. The anorexia of aging. Nutrition 2000; 16: 983-95.

27. Visvanathan R, Macintosh C, Callary M et al. The nutritional status of 250 older Australian recipients of domiciliary care services and its association with outcomes at 12 months. J Am Geriatr Soc 2003; 51: 1007-11. 
28. Fulton MM, Allen ER. Polypharmacy in the elderly: a literature review. J Am Acad Nurse Pract 2005; 17: 123-32.

29. Jorgensen T, Johansson S, Kennerfalk A et al. Prescription drug use, diagnoses, and healthcare utilization among the elderly. Ann Pharmacother 2001; 35: 1004-9.

30. Chung MK, Bartfield JM. Knowledge of prescription medications among elderly emergency department patients. Ann Emerg Med 2002; 39: 605-8.

31. Mangoni AA, Jackson SH. Age-related changes in pharmacokinetics and pharmacodynamics: basic principles and practical applications. Br J Clin Pharmacol 2004; 57: 6-14.

32. Hohl CM, Dankoff J, Colacone A et al. Polypharmacy, adverse drug-related events, and potential adverse drug interactions in elderly patients presenting to an emergency department. Ann Emerg Med 2001; 38: 666-71.

33. Budnitz DS, Pollock DA, Weidenbach KN et al. National surveillance of emergency department visits for outpatient adverse drug events. JAMA 2006; 296: 1858-66.

34. Woolcott JC, Richardson KJ, Wiens MO, et al. Meta-analysis of the impact of 9 medication classes on falls in elderly persons. Arch Intern Med 2009; 169: 1952-60.

35. Chan M, Nicklason F, Vial JH. Adverse drug events as a cause of hospital admission in the elderly. Intern Med J 2001; 31: 199205.

36. Caplan GA, Williams AJ, Daly B, et al. A randomized, controlled trial of comprehensive geriatric assessment and multidisciplinary intervention after discharge of elderly from the emergency department - the DEED II study. J Am Geriatr Soc 2004; 52 : 1417-23.

37. Basic D, Conforti DA. A prospective, randomised controlled trial of an aged care nurse intervention within the Emergency Department. Aust Health Rev 2005; 29: 51-9.

38. Gagnon AJ, Schein C, McVey L et al. Randomized controlled trial of nurse case management of frail older people. J Am Geriatr Soc 1999; 47: 1118-24.

39. Guttman A, Afilalo M, Guttman R et al. An emergency department-based nurse discharge coordinator for elder patients: does it make a difference? Acad Emerg Med 2004; 11: 1318-27.

40. Miller DK, Lewis LM, Nork MJ et al. Controlled trial of a geriatric case-finding and liaison service in an emergency department. $\mathrm{J}$ Am Geriatr Soc 1996; 44: 513-20.

41. Runciman P, Currie CT, Nicol M et al. Discharge of elderly people from an accident and emergency department: evaluation of health visitor follow-up. J Adv Nurs 1996; 24: 711-8.

42. Cornette $\mathrm{P}$, Swine $\mathrm{C}$, Malhomme $\mathrm{B}$, et al. Early evaluation of the risk of functional decline following hospitalization of older patients: development of a predictive tool. Eur J Public Health 2006; 16: 203-8.

43. Dendukuri N, McCusker J, Belzile E. The identification of seniors at risk screening tool: further evidence of concurrent and predictive validity. J Am Geriatr Soc 2004; 52: 290-6.

44. Hustey FM, Mion LC, Connor JT et al. A brief risk stratification tool to predict functional decline in older adults discharged from emergency departments. J Am Geriatr Soc 2007; 55: 1269-74.

45. Lee JS, Schwindt G, Langevin M et al. Validation of the triage risk stratification tool to identify older persons at risk for hospital admission and returning to the emergency department. J Am Geriatr Soc 2008; 56: 2112-7.

46. McCusker J, Bellavance F, Cardin S et al. Screening for geriatric problems in the emergency department: reliability and validity. Identification of Seniors at Risk (ISAR) Steering Committee. Acad Emerg Med 1998; 5: 883-93.
47. McCusker J, Bellavance F, Cardin S et al. Detection of older people at increased risk of adverse health outcomes after an emergency visit: the ISAR screening tool. J Am Geriatr Soc 1999; 47: 1229-37.

48. McCusker J, Dendukuri N, Tousignant P et al. Rapid two-stage emergency department intervention for seniors: impact on continuity of care. Acad Emerg Med 2003; 10: 233-43.

49. McCusker J, Jacobs P, Dendukuri N et al. Cost-effectiveness of a brief two-stage emergency department intervention for high-risk elders: results of a quasi-randomized controlled trial. Ann Emerg Med 2003; 41: 45-56.

50. Meldon SW, Mion LC, Palmer RM et al. A brief risk-stratification tool to predict repeat emergency department visits and hospitalizations in older patients discharged from the emergency department. Acad Emerg Med 2003; 10: 224-32.

51. Rowland K, Maitra AK, Richardson DA et al. The discharge of elderly patients from an accident and emergency department: functional changes and risk of readmission. Age Ageing 1990; 19: 415-8.

52. Salvi F, Morichi V, Grilli A et al. Predictive validity of the Identification of Seniors At Risk (ISAR) screening tool in elderly patients presenting to two Italian emergency departments. Aging Clin Exp Res 2009; 21: 69-75.

53. Warburton RN, Parke B, Church $\mathrm{W}$ et al. Identification of Seniors at Risk: process evaluation of a screening and referral program for patients aged $>$ or $=75$ in a community hospital emergency department. Int J Health Care Qual Assur Inc Leadersh Health Serv 2004; 17: 339-48.

54. Inouye $\mathrm{SK}$, van Dyck $\mathrm{CH}$, Alessi CA et al. Clarifying confusion: the confusion assessment method. A new method for detection of delirium. Ann Intern Med 1990; 113: 941-8.

55. Folstein MF, Folstein SE, McHugh PR. "Mini-mental state". A practical method for grading the cognitive state of patients for the clinician. J Psychiatr Res 1975; 12: 189-98.

56. Wilber ST, Lofgren SD, Mager TG et al. An evaluation of two screening tools for cognitive impairment in older emergency department patients. Acad Emerg Med 2005; 12: 612-6.

57. Huff JS, Farace E, Brady WJ et al. The Quick Confusion Scale in the ED: comparison with the Mini-Mental State Examination. Am J Emerg Med 2001; 19: 461-4.

58. Gerety MB, Williams JW Jr, Mulrow CD et al. Performance of case-finding tools for depression in the nursing home: influence of clinical and functional characteristics and selection of optimal threshold scores. J Am Geriatr Soc 1994; 42: 1103-9.

59. Hustey FM. The use of a brief depression screen in older emergency department patients. Acad Emerg Med 2005; 12: 905-8.

60. Fabacher DA, Raccio-Robak N, McErlean MA et al. Validation of a brief screening tool to detect depression in elderly ED patients. Am J Emerg Med 2002; 20: 99-102.

61. Mahoney FI, Barthel DW. Functional Evaluation: the Barthel Index. Md State Med J 1965; 14: 61-5.

62. Katz S, Ford AB, Moskowitz RW et al. Studies of illness in the aged. The Index of ADL: a standardized measure of biological and psychosocial function. JAMA 1963; 185: 914-9.

63. Lawton MP, Brody EM. Assessment of older people: self-maintaining and instrumental activities of daily living. Gerontologist 1969; 9: 179-86.

64. George LK, Fillenbaum GG. OARS methodology. A decade of experience in geriatric assessment. J Am Geriatr Soc 1985; 33: 607-15.

65. McCusker J, Bellavance F, Cardin S, et al. Validity of an activities of daily living questionnaire among older patients in the emergency department. J Clin Epidemiol 1999; 52: 1023-30. 
66. Podsiadlo D, Richardson S. The timed "Up \& Go": a test of basic functional mobility for frail elderly persons. J Am Geriatr Soc 1991; 39: 142-8.

67. Guigoz Y, Vellas B, Garry PJ. Assessing the nutritional status of the elderly: the Mini Nutritional Assessment as part of the geriatric evaluation. Nutr Rev 1996; 54: S59-65.

68. Posner BM, Jette AM, Smith KW et al. Nutrition and health risks in the elderly: the nutrition screening initiative. Am J Public Health 1993; 83: 972-8.

69. Visvanathan R, Zaiton A, Sherina MS et al. The nutritional status of 1081 elderly people residing in publicly funded shelter homes in Peninsular Malaysia. Eur J Clin Nutr 2005; 59: 318-24.

70. de Groot LC, Beck AM, Schroll M et al. Evaluating the DETERMINE Your Nutritional Health Checklist and the Mini Nutritional Assessment as tools to identify nutritional problems in elderly Europeans. Eur J Clin Nutr 1998; 52: 877-83.

71. Kyle UG, Morabia A, Slosman DO et al. Contribution of body composition to nutritional assessment at hospital admission in 995 patients: a controlled population study. Br J Nutr 2001; 86: 725-31.

72. Omran ML, Morley JE. Assessment of protein energy malnutrition in older persons, Part I: History, examination, body composition, and screening tools. Nutrition 2000; 16: 50-63.

73. Winterstein AG, Sauer BC, Hepler CD et al. Preventable drug-related hospital admissions. Ann Pharmacother 2002; 36: 1238-48.

74. Gallagher P, Ryan C, Byrne S et al. STOPP (Screening Tool of Older Person's Prescriptions) and START (Screening Tool to Alert doctors to Right Treatment). Consensus validation. Int $\mathrm{J}$ Clin Pharmacol Ther 2008; 46: 72-83.

75. Gallagher P, O'Mahony D. STOPP (Screening Tool of Older Persons' potentially inappropriate Prescriptions): application to acutely ill elderly patients and comparison with Beers' criteria. Age Ageing 2008; 37: 673-9.

76. Dunnion ME, Kelly B. From the emergency department to home. J Clin Nurs 2005; 14: 776-85.

77. Hustey FM, Meldon SW. The prevalence and documentation of impaired mental status in elderly emergency department patients. Ann Emerg Med 2002; 39: 248-53.

78. Lang PO, Heitz D, Hedelin G et al. Early markers of prolonged hospital stays in older people: a prospective, multicenter study of 908 inpatients in French acute hospitals. J Am Geriatr Soc 2006; 54: 1031-9.

79. McCusker J, Cole MG, Dendukuri N et al. Does delirium increase hospital stay? J Am Geriatr Soc 2003; 51: 1539-46.
80. Han JH, Zimmerman EE, Cutler $\mathrm{N}$ et al. Delirium in older emergency department patients: recognition, risk factors, and psychomotor subtypes. Acad Emerg Med 2009; 16: 193-200.

81. McCusker J, Cole M, Abrahamowicz M et al. Delirium predicts 12-month mortality. Arch Intern Med 2002; 162: 457-63.

82. Drame M, Dia PA, Jolly D et al. [Factors predictive of long-term mortality in patients aged 75 years or older hospitalized from the emergency department: the SAFES cohort]. Presse Med 2009; 38: 1068-75.

83. Meldon SW, Emerman CL, Schubert DS et al. Depression in geriatric ED patients: prevalence and recognition. Ann Emerg Med 1997; 30: 141-5.

84. Hustey FM, Smith MD. A depression screen and intervention for older ED patients. Am J Emerg Med 2007; 25: 133-7.

85. Barefoot JC, Schroll M. Symptoms of depression, acute myocardial infarction, and total mortality in a community sample. Circulation 1996; 93: 1976-80.

86. Foo CL, Chan KC, Goh HK et al. Profiling acute presenting symptoms of geriatric patients attending an urban hospital emergency department. Ann Acad Med Singapore 2009; 38: 515-6.

87. Campbell AJ, Borrie MJ, Spears GF et al. Circumstances and consequences of falls experienced by a community population 70 years and over during a prospective study. Age Ageing 1990; 19: 136-41.

88. Campbell AJ, Spears GF, Brown JS et al. Anthropometric measurements as predictors of mortality in a community population aged 70 years and over. Age Ageing 1990; 19: 131-5.

89. Classen DC, Pestotnik SL, Evans RS et al. Adverse drug events in hospitalized patients. Excess length of stay, extra costs, and attributable mortality. JAMA 1997; 277: 301-6.

90. Smith MJ, Breitbart WS, Platt MM. A critique of instruments and methods to detect, diagnose, and rate delirium. J Pain Symptom Manage 1995; 10: 35-77.

91. Borson S, Scanlan J, Brush M et al. The Mini-Cog: a cognitive 'vital signs' measure for dementia screening in multi-lingual elderly. Int J Geriatr Psychiatry 2000; 15: 1021-7.

92. Vellas BJ, Wayne SJ, Romero L et al. One-leg balance is an important predictor of injurious falls in older persons. J Am Geriatr Soc 1997; 45: 735-8.

93. Carpenter CR, Scheatzle MD, D'Antonio JA et al. Identification of fall risk factors in older adult emergency department patients. Acad Emerg Med 2009; 16: 211-9. 